\title{
Re-visions in School Stories
}

\author{
Cheryl McMillan
}

$\mathrm{S}$ chool stories, as fictional representations of school culture, commonly explore themes and motifs relevant to both schooling and to the socialisation of children of all ages. Over its long history, the genre evidences shifting strategies for representing both the school and school culture, particularly in relation to aspects of class and gender, but the concept of agency has always remained crucial to such representations. Agency, seen as 'a desirable aim of emancipatory education' (Allen 1998, p.353), implicates the relative positioning of a subject and reflects our potential to act independently of external power structures. Some recent examples of the school story have not only narrativised the question of agency but also used strategies which allow a more open positioning of readers and which encourage reader agency. In doing so, these texts appear to point to a transition in the traditional power structures of the school and schooling.

In drawing examples from different kinds of texts and from different periods, I will not here be attempting an historical survey, but will focus on the act of narration perceived, in Shlomith Rimmon-Kenan's terms, as a dynamic process through which texts and readers might establish a mode of access to apprehending or re-engaging with reality, and hence with representation. She argues that in the shifting literary approaches to ways of viewing the world, such as mimesis, representation, intertextuality and metatextuality, access has generally been restricted. She suggests that an approach to representation and subjectivity through narration 'also grants the narrating subject access to agency within (or in spite of) the ideological constructs to which he or she is subjected' (Rimmon-Kenan 1996, p.22). 'Narrating subject' is later extended to apply to readers (p. 129). To an extent the school stories I am citing here trace a shifting pattern of textuality, each representational kind having its own possibilities and limitations. However, drawing from Rimmon-Kenan's theory and restating it in terms of the school stories outlined above, I want to ask how effectively the narrative processes of more recent stories grant young readers access to agency within (or in spite of) the ideologies served by the text. Because a concern with reader agency, in any formulation of the idea, is not really reflected in the earlier school stories of my review, my critical emphasis tends to fall on the narrative product in these texts, rather than on narrative processes which activate reader agency.

School stories represent official forms of the schools and install many familiar school characters and motifs. Pointing to a school story tradition, in part established by Talbot Baines Reed in the nineteenth century, Ray identifies some 'staple ingredients'. She refers to 'the arrival of the new boy and his adjustment to school ways', a motif which acts as a reminder that many stories have been written to boy or girl readerships. Other well recognised motifs include school matches, the school magazine, conflict between juniors and seniors, concerts, friendships and rivalries, and villainies and blackmail (Ray 1996, p.349). Bullying, a well-publicised contemporary issue, is a perennial staple. To this list could be added: conflict between pupils and teachers, themes of freedom and restraint, and achievement and failure.

Staples such as these may shape the primary narrative but texts use them and their variants for a number of purposes and in different ways. For example, in more recent fiction they have provided backgrounds in which to examine multi-cultural. gender and other social issues that affect children in schools (p.357). A narrative treatment or thematising of such issues can be an effective means of drawing attention to some of the value systems operating within the society as well as within the school. However, while reflecting an interest in the shifting historical and societal framework within which schools operate, this kind of treatment usually positions readers conservatively. To examine some other possibilities and to provide examples of different narrative styles and strategies, I will draw on a diverse range of texts, including novels for young readers and more sophisticated readers, and also including a picture book. The strategies used reflect some of the different possibilities and limitations for each genre, and the appeal and age readership of these texts varies, but the staples mentioned above recur to some degree in all the stories and the stories pivot on the institutionalized school and schooling. In their narrative approaches the texts seem testament to their time of writing, though I say this reservedly, since traditional approaches are found in very recent school stories.' I 
have looked to the picture book and the possibilities of its dual codes for evidence of a particularly flexible reader positioning.

Three main tendencies in school stories can be identified for inscribing the school. First, there are texts in which the ideologies carried by the school tend to be represented as unproblematic. Stalky and Co. (Kipling 1987 [1899]) and The Naughtiest Girl is a Monitor (Blyton 1993 [1945]) are examples I will consider here, while I keep in mind Hollindale's point about the dangers of commentating on such ideology 'as if it were a political policy, when in fact it is a climate of belief (see Hollindale, 1988, p. 19). Stalky and Co. has been seen as an 'attempt to subvert the (school story) genre', as it broke new ground in its representation of subversive or uninhibited language and behaviour in the school (Watson 1987, p.199). However, the same 'political' language and behaviour does not seriously challenge ideologies of class and gender, even if it satirises the school. ${ }^{2}$ Second, there are texts which, seemingly informed by liberal humanism, narrativise or thematise some of the values attached to schooling without self-reflexively drawing attention to fictional processes. Of this kind, Thunder and Lightnings (Mark 1976) and Cannily, Cannily (French 1981) use themes of friendship and self-discovery as a means of overcoming the alienating values of the school. Mark adeptly uses the primary narrative to build a focus on codes and their power to facilitate, as in the friendship between two boys, or to constrain and inhibit, as in the communication of the school. A third tendency is for texts to invite readers to "read with a more reflective and detached awareness of how the processes of fiction are operating as they read' (Mackey 1990, p.179). The Turbulent Term of Tyke Tiler (Kemp 1977) works in this way, carrying a constructed 'passive' ideology of gender to the end of the story before exposing it as culturally determined. Frindle (Clements 1996), a junior novel, centres its narrative on the production of word meaning and constructs a win/win situation for school and students. Captain Abdul's Pirate School (McNaughton 1994) is an exceptional school story, not only in its utilisation of the picture book's ironic form to explicitly challenge the institutionalized school and the ideologies it carries, but in directing these concerns to a very young audience.
School stories may tend to a particular expression of ideology and formation of reader positions, but may be moderated and complicated by a number of factors. For example, The Tower Room (1990) uses the Rapunzel intertext to dialogise a version of growing sexual awareness and the transformation of the child into adulthood. This strategy might then seriously challenge gender representations, but I think the text steers back into a rephrasing of traditional gender expectations and reconfirmation of traditional school values. Another moderating factor emerges from reading a text from a quite distant historical standpoint. In this case readers may interrogate the implicit ideologies of Stalky and Co., for example, not because of the textual process itself, but because prevailing cultural emphases demand their review. From a contemporary perspective there is a pervasive sense of narrowly defined boundaries of class and gender in Kipling's narrative, although the morality of the text, language register, use of irony and satire, and story type do not produce a strongly didactic work.

\section{Issues of Class and Gender}

Based on British school systems, Stalky and Co., The Naughtiest Girl is a Monitor, Thunder and Lightnings, The Turbulent Term of Tyke Tiler and The Tower Room are realist in orientation. Stalky and Co. bases the school experience it recounts on Kipling's own school experiences in England in the late 1870s and the book is dedicated to his school headmaster at the United Services College, North Devon. Written almost as a memoir, Stalky and Co.'s linguistic features and context are obviously tied to the conventions of an earlier period. As the narrative represents a middle-class grammar school, a boarding school, catering for boys who were going on to military college, there are central issues of class and gender, and the ideologies they serve seek to preserve the class system and build up the male values attached to a particular class. The Naughtiest Girl is a Monitor is a product of Blyton's school story period (Sunny Stories) and the author chooses a progressive school setting (middle-class) for Whyteleafe, presumably using the coeducational boarding school as a means of attracting young boy and girl readers. Thunder and Lightnings uses a local, co-educational primary school as its school setting. The school in Cannily, Cannily seems to be an 
Australian counterpart. Both represent an academically and emotionally impoverished institution at odds with the values which the main character learns at home. The Turbulent Term of Tyke Tiler's Cricklepit Combined in Exeter is a state school whose pupils are mainly working class. In the story they follow a path to Dawson Comprehensive, and if they achieve A levels, as did Beryl who was 'better endowed intellectually' (Geras 1990, p.31), may move on to the College of Further Education. Egerton Hall, a traditional English boarding school for middle-class girls, is an all female enclave where girls in attendance are sheltered from the outside world as the title, The Tower Room, suggests.

Each of the school settings in these realist works encodes the customs and discourses of the represented class. Schools themselves often embody the status of the classes they attract. For example, privileged schools, as in Stalky and $C o$., arrange space not only for specialist purposes but as privately claimed territory. The school in The Turbulent Term of Tyke Tiler operates in a run-down building whose bell-tower crumbles. Stalky and Co. is concerned with school 'tradition', whereas Cricklepit Combined's 'history' is discussed.

Teachers, especially in Stalky and Co, The Tower Room and The Turbulent Term, are often characterized as the educated middle-class and use a fixed register which is formal, tends to ironic humour and reflects a school discourse. Frequent allusions are made to traditional subject matter and classic intertexts. Such language may be discriminatory both socially and culturally (see Partington 1998, p.111), and is essentially hierarchical. However, in Frindle, as the traditional use of the word pen is broken down and displaced by the word 'frindle', which is Nick's invention, Nick's teacher concedes the new usage. Since she has previously written Nick a letter stating the terms of her acceptance (that it appear in the dictionary), both teacher and student are afforded agency in the story outcome. The integration of the new word into common usage acts as a metonym for the breakdown of language hierarchies, and the dictionary's change and growth implicates such processes within the school environment. In Thunder and Lightnings Mark uses humour to foreground and ridicule the school's confusing jargon and failure to engage with pupils. The Turbulent Term deals with the idea of the alienating register gap between teachers and pupils by characterizing Tyke as mediator in the communication between Danny (who has a speech defect) and the school. In spite of Tyke's efforts, the school decides that Danny should be transferred to a school with 'facilities to deal with children of that type'. But 'type' indicates not speech impediment but socially inferior, as the teachers suggest of his social background ('awful mother, father in prison, filthy home') (Geras 1990, p. 70 ).

While teacher discourse has a potential to reflect social hierarchies, it can also be gender discriminatory. Utilising poststructuralist feminist perspectives, recent studies have pointed beyond teachers and the influence they exert to either reproduce or reform gendered discourse in schools to 'the broader sociopolitical context of gender-power relations (Kamler 1999, p. 193). Teachers may then be viewed as "participants in a negotiation that always involves the intersection of multiple social and political agendas' (Wilson Keenan, Solsken and Willett 1999, p.37). The Turbulent Term acknowledges that gendered discourse has a context beyond the formal structures of the school by implicating readers as subjected to the assumptions held in language, narrative schemata and sociopolitical biases.

Ideologies of class are explicitly and implicitly encoded in Stalky and Co, but explicit class statements are not encoded self-consciously. Teachers and pupils within the 'Coll' occupy positions that are stratified as part of a strongly hierarchical system, with the headmaster, housemaster, prefects, seniors and fags taking clearly delineated roles. The discourse reflects hegemonic interests in its many references to landed families and the school's ties to the upper class. Even seemingly horizontal divisions, such as the house system, are designed to promote competition and a form of party allegiance in the cause of 'the honour of the house'. Having served their time, old boys when they return to visit the school are permitted, according to their rank, to fraternise with the headmaster. Thus, in the horizontal framework suggested by fraternity, the emphasis is still on status and position. 


\section{Power Plays}

The motif of bullying, typically inscribed as a power play between students, appears as a means of maintaining discipline within the ranks in Stalky and Co. For example, Stalky, Beetle and M'Turk conspire with Reverend John, the chaplain, to punish two seniors bullying 'little Clewer': 'you can use your influence' - a purely secular light flickered in the chaplain's eye - 'in any way you please to - to dissuade him' (Kipling 1987, p.117). Kipling inscribes the double standard, and the school's preference for discipline at the expense of the moral training of the student. The example also encodes a motif where violated rights are redressed by pupils themselves, sometimes with the endorsement of teachers. In The Turbulent Term of Tyke Tiler Tyke cheats on the verbal reasoning tests in an effort to protect Danny's right to stay at the school. In this case, Tyke is exonerated because the values exemplified in her independent actions prevail over school rules. Kemp is explicitly concerned with the conventions operating within the text, as the book's alliterative title suggests. The Turbulent Term and Frindle represent schools which are less stratified than those in the other texts of this discussion. Within the school's formal structures Tyke and Nick are characterised as having some agency to negotiate with adults in positions of authority.

The so-called 'sensible' and democratic system of government operating in the boarding school in The Naughtiest Girl is a Monitor, where in the School Parliament the child characters make the rules and decide what best serves their own interests, sideswipes democracy. The children selected as leaders form a hierarchy of their own - head boy and head girl, monitors (also called 'jurors') and children - and impose a rigid system of management. The head boy and head girl act as judges, instead of taking a vote, so the system at Whyteleafe in fact mirrors the division held in the conventional teacher/pupil hierarchy.

Unsurprisingly, the Blyton text places a strong emphasis on right and wrong behaviour, 'for it was part of the rule of the school that every child should be helped with his or her faults' (Blyton 1993, p.9), and the child characters feel guilty and ashamed if they have transgressed. There is a strongly conformist attitude and even Julian, a newcomer to Whyteleafe who is characterized as nonconformist in line with the stated progressive school approach to education, is converted into the stereotypically ideal bourgeois school child (smart, popular, hard-working and going to be a doctor).

If The Naughtiest Girl constructs an inflexible reward and punishment system, Stalky and Co. shows that the system may be eschewed in favour of one's birthright. In the matter of fox-shooting M'Turk, having been caught out of bounds, speaks to Colonel Dabney, the owner of the land, 'as one gentleman to another':

Forgotten - forgotten was the College and the decency due to elders! M'Turk was treading again the barren purple mountains of the rainy west coast, where in his holidays he was viceroy of four thousand naked acres, only son of a threehundred-year-old house, lord of a crazy fishing boat, and the idol of his father 's shifless tenantry. It was the landed man speaking to his equal deep calling to deep - and the old gentleman acknowledged the cry.

(Kipling 1987, p.20)

Kipling's lexical choices to describe M'Turk - 'viceroy', 'only son', 'lord', 'idol of father's shiftless tenantry' and 'landed man' - have a dual effect. They combine notions of privilege not only with the aristocracy but with the male line. Transgression is absolved by class status. 'Shiftless tenantry' refers then to maintaining one's rightful place, as Colonel Dabney bluntly explains, when he blames the evil of poaching on his land on a man misplaced: 'This comes of promoting a fisherman fisherman - from his lobster pots' (p.20).

Linguistic features such as register and tone in the realist school stories serve to acknowledge an official school discourse, which may have class and power implications. In Stalky and Co. the tone of the third person narrator is light-hearted, reflecting the author's attitude of approval and complicity towards schoolboy pranks and their flouting of authority. The narrator thus validates this part of informal school life rather than the formal school curriculum, the latter seeming to be 'caught' incidentally. Of course, in texts driven by class motives of another 
kind, anti-authoritarian behaviour may be construed as beyond the parameters of acceptance. Similarly, the male standards and values displayed might be deemed unacceptable if the gender roles were female. That the narrative represents particular memories of Kipling's own school days predetermines the register and empathetic tone of the text, a tone of barely suppressed mirth, a mellowing of the open mirth of his protagonists. Traces of irony and satire invite a kind of reader distance but representations of class and gender suggest 'a climate of belief.

The story opening frames the narrative accordingly. While it introduces the overarching tone of the narrative, it also seems class and gender differentiated:

\section{In summer all right-minded boys built huts in the furze-hill behind the College-little lairs whittled out of the heart of the prickly bushes, full of stumps, oddroot-ends, and spikes, but, since they were strictly forbidden, palaces of delight. \\ (Kipling 1987, p.13)}

A causal relationship is established between what is forbidden and the metaphor relating to the out-of-bounds huts. Then by juxtaposing 'palaces' and its associative link with the upper classes with 'delight' (of rulebreaking), the metaphor in effect frees the upper classes from regular constraints and even suggests that the tension between desire and constraint is character-building. The positive connotation in 'right-minded' attached to the rule-breaking boys reveals the authorial narrator's close identification with the boy's' trangressive spirit as well as with the boys themselves. It is as if the narrator is in fact one of the boys, because the sentence can also be read as if focalized by the boys in question. The discourse's multiple affirmation of the boys and their actions then works to approbate 'lairs' which is already trivialised by 'little' and 'whittled', in effect suggesting that 'wild', active behaviour is the realm of the male.

The schema of challenging or undermining the school's authority may operate at narratival level, where it can be encoded in motifs such as the school prank or practical joke or in allowed/forbidden dichotomies and nonconformity. Almost endemic in school stories, such motifs may be used to characterize the informal side of school life in opposition to its formal and serious culture. They can function in different ways, often as a source of humour or to create and develop a sense of freedom and agency which the constructed framework of the school's authority may deny pupils/ characters.

\section{Carnivalesque Texts}

Another possible function suggested by this kind of conflict is for the text to operate as carnivalesque. The carnivalesque (after Bakhtin) derives from the essential spirit and drama of carnival which reflected the unrestrained and diverse expression of the people and which playfully suspended official forMs Since the camivalesque effectively inscribes two worlds, the official world and the world outside it, it is a useful mode for establishing a dialogue between two contexts or two textual positions and for mocking and playfully challenging the established order (see Bakhtin 1965, p. 6). Children's camivalesque texts inscribe narratives and themes of nonconformity, express opposition to authoritarianism and seriousness, and foreground relative 'truths' and ideologies (Stephens 1992, pp.121-122). Stephens has pointed to the school story as potentially carnivalesque, because "it has an inherent or potential conflict between the subjectivity of children and the authority of adults' (p.157). Through carnivalesque modes the school can also be constructed as Other, and its authority may be subverted by making it appear irrelevant or distant to the real concerns of its pupils. In establishing oppositional positions a text can offer readers a negotiative framework. In spite of their discourse of challenge, carnivalesque strategies tend, like the carnival, to produce conservative ends ${ }^{3}$ and endings and so hardly dislodge the metanarratives of children's fiction. Nevertheless, carnivalesque strategies which foreground the social construction of meaning can empower readers, and distance them from the shaping impulse of text (p.156).

The Turbulent Term, Frindle and Captain Abdul's Pirate School are examples of children's carnivalesque. Working within the narrative framework of their respective genres, these texts mock or challenge the structures of officialdom. They all make use of metafictive strategies to draw attention to linguistic and societal convention, and sustain a challenge to the values of the school. In The Turbulent 
Term the collapse of the bell-tower under Tyke's weight suggests a breaking down of old ways, just as 'pen' is displaced by 'frindle' in Frindle. In Captain Abdul's Pirate School the pupils mutiny to outwit their pirate teachers. The effect in all these texts is to displace the values of the traditional school, at least to some extent, and to offer readers access to agency by providing interrogative reading positions. Of the three, it seems to me that Frindle, in its narrativisation of convention and change, most successfully dispels the image of the unyielding school and in its ending works to resolve school and student oppositions. Another rare feat is to afford agency to the main student character without compromising the main teacher character's agency.

\section{Positioning Readers}

Representative of a thematic approach, Thunder and Lightnings and Cannily, Cannily, use a first person narration focalized by the main character, which tends to subject young readers to the point of view of that narrator. The shaping power of this technique implicates reader agency (see Stephens 1992, pp.68-70). However, single identification is somewhat qualified in these stories because the subjectivity of the characters is formed through a kind of negotiation with an oppositional social world (the school and some of its reflected values in the community) and a thematised challenge to its socializing practices. Secondly, both stories deal with significant school friendships in which the perceptions of two friends are altered and modified by each other. These texts follow strongly humanist traditions and privilege a particular set of educative values, for example, lived knowledge over 'school' knowledge. The more sophisticated text, Thunder and Lightnings, develops a theme of empowerment through language. Andrew's friend, Victor, can hardly read at school and doesn't like learning, but is fluent in reading the language of the planes and expert in his knowledge of them. Jan Mark's use of dialogue in Thunders and Lightnings often draws attention to gaps and incongruities in language, thereby encouraging active readers. These strategies are not overt but work towards thematic outcomes.

Strategies which help to distance readers in The Tower Room rest mainly on its intertextual mode. The relationship between the focused text and the Rapunzel fairytale suggests a possible interpretive frame for readers (see McCallum 1996, p.401), and so fairytale elements such as fantasy, transformation and overcoming are given meaning in the context of the school and a 'school self' (Geras 1990, p.38). The tower symbolizes isolation from the realities of life, which suggests the enclosed school environment. What is forbidden in this school is a relationship with the opposite sex. It is in the tower room that the forbidden liaisons between Megan and Simon, a science teacher, take place, resulting in their leaving the school. Freed from the school's constraints, Megan is ambivalent towards the protection it offers, but ultimately desires to return. This ambivalence is realised by the suggestion in the narrative that Megan and Simon's flat is another kind of tower. Since emancipation, symbolized by the cutting of Megan's hair, means returning to school, the text in effect reaffirms a set of traditional school values.

By contrast, The Turbulent Term sustains its challenge to school authority. This challenge is grounded in issues of gender and addresses themes of friendship and personal growth. Tyke breaks the rules in an effort to protect Danny. At the same time she learns the rules. When she is finally able to use the word 'mendacity' appropriately in her interview with the headmaster (he has previously favoured the word), she succeeds in winning him over to her point of view. Tyke thus succeeds in closing a gap induced by the alienation of unshared register, although , she must do so on the school's terMs In the end the narrative identifies Tyke as female and readers' attention is drawn to the formation of identity through a constructed story logic and thus to the linguistic rules and conventions that can shape their reading. Readers subjected to the authorial dupe(s) are implicated in the way in which language functions schematically to predispose story outcomes. The effect is parodic in the sense of encoding and at the same time subverting a social assumption.

Within her school story framework Kemp addresses the question of gender assumptions through notions such as athleticism, discipline, friendship and fighting, to which gender specific discourses are often attached. Colin McNaughton shows a similar interest in Captain Abdul's 
Pirate School but the text is unlike most school stories in its use of the picture book form to invert and parody the traditional school story. Kemp's text uses metafictive techniques to expose gender assumptions but does so against a story background that is otherwise traditional. This is, of course, part of her strategy, as she installs a gendered discourse implicitly before rendering it explicit. In this case the signal of metafictiveness operates by means of a short circuit delivered after the narrative has carried implied readers in a different mode (see Moss 1992, p.58). However, Captain Abdul's Pirate School belongs rather to a wave of pervasively and selfconsciously metafictive works for young children which challenge the discourses of the past through parodic forms.

Captain Abdul's Pirate School displays all of the following characteristics which Bakhtin attributed to carnivalesque parody: playfulness, laughter which is 'gay, triumphant, and at the same time mocking and deriding', excesses, grotesquery, and a sense of 'the gay relativity of prevailing truths and authorities' (Bakhtin 1965, p.11). To set up a dialogical framework within which the school's processes can be challenged, the text establishes several sites of transgression, each of which parodies an official world structure. To begin with, the pirate school of the narrative is a playful and humorous inversion of standard principles of traditional schooling; school rules, school register, moral and disciplinary training and lesson material are carnivalised. The use of a pirate story allows an altered moral frame within a school structure (see Stephens 1992, p.157). The pirate characters act as material embodiments of the carnivalesque characteristics outlined above, and so function to displace and undermine serious culture. The narrative re-signifies motifs of bullying, cheating and the midnight feast by encoding their opposing official world values as travesties.

In the story opening parental authority is parodied: 'My stinking dad has sent me here because he says I'm a big softie! (Just because I like writing poems and painting pictures!) ... He says that when he was a kid he wanted to be a pirate and so should I. He says I should be grateful.' The conventional poses and questionable traditions being undermined here pre-empt a number of such poses and traditions challenged in the discourse and a ridiculing and playfully anti-authoritarian tone is established. However, this tone is not then carried by the first person child narrator of the diary narrative, but by the pictorial code's carnivalised representation of events and by verbal markers in the pictures, such as the speech balloons and signage. Still, the narrative of the diary inscribes the carnivalised position even while it reinscribes the practices and values of the traditional school world.

The use of the diary form in the text's polyphonic structure constructs a distance from events not usually granted in a first person narrating voice. In this case, the distance is from the carnivalised world of the visual code, and also from the narrating voice, because the diary narrative appears as boldly framed segments superimposed on the visual code. Effectively this positions readers to observe a process of re-negotiation offered by carnivalesque parody. The position is made quite clear in the visual code of the double-spread where the pupils are introduced to the pirate teachers. Here there are two lineups: the pirates, as grotesques, face an audience ambiguously encoded as the shadowy head and shoulder outlines of the pupils positioned exactly as the implied reading audience.

Temporarily hidden in its parody of the traditional concept of school and its values is the gendered discourse constructed by the text. The framing sentences cited above establish a discourse of masculinity, although the narrator's parenthesised comment in a tone of indignation could alert readers to the narrative's duplicity. Whereas in The Turbulent Term the discourse examines gender in relation to subjectivity as well as to language and its signifying practices, Captain Abdul's Pirate School foregrounds language and social conventions as instrumental in constructing gender roles. The speech balloons in comic mode emphasise language play. For example, the pupil mutineers set sail, giving orders such as 'Fluke the orlop!' and 'Clovehitch the sheepshank!' and 'Grease the throatcringles!' The micro-text's playful use of unfamiliar generic terms metafictively reflects the macro-textual strategy which parodies official speech, generic discourses and conventions and structures of authority.

In conclusion, school stories have continued to represent 
school as a composition of formality and the authorities vested in that formality. At the same time, and according to their generic framework, the stories address notions of freedom and ways in which child characters develop subjectivities in relation to authority. By using the narrative or the narrative codes to expose and challenge the social systems perpetuated by the discourse of the school, some more recent school stories have worked to reappraise some of the power relations of past discourses. In many respects this fictional reappraisal, of schooling, of gender identities, and of access to agency, reflects a wider cultural climate of self-consciousness and challenge. More especially, it echoes educationalists' current emphasis on the school's potential for change and contestation and on human agency within the structures and discourses of the school environment. For the readers of school stories, access to agency within or in spite of the social worlds foregrounded in these stories may mean an alertness to the shaping effects of discourse, an alertness which the stories themselves, as indeed the school, may foster.

\section{NOTES}

1 The Harry Potter series, for example, uses a traditional approach, even while it uses a fantasy framework.

2 Hollindale suggests that 'classic' works such as Stalky and $\mathrm{Co}$. do sometimes 'test and undermine some of the values which they superficially appear to be celebrating' (Hollindale 1988, p.20).

3. Relating the 'two-world condition' of the carnivalesque to parody, Linda Hutcheon argues that such forms are ambivalent, because they are driven by conservative and revolutionary forces (Hutcheon 1985, p.26).

\section{REFERENCES}

Allen, Jennifer (ed) (1998) 'Glossary', in Sociology of Education: Possibilities and Practices. Katoomba, Social Science Press.

Bakhtin, Mikhail (1984) [1965] Rabelais and His World. Helene Iswolsky (trans.). Bloomington, Indiana University Press.

Blyton, Enid (1993) [1945] The Naughtiest Girl is a Monitor. Melbourne, Budget Books.
Clements, Andrew (1996) Frindle. New York, Simon and Schuster.

French, Simon (1981) Cannily, Cannily. Sydney, Angus and Robertson.

Geras, Adele (1990) The Tower Room. London, Hamish Hamilton.

Hollindale, Peter (1988) 'Ideology and the Children's Book' in Signal 55: 3-22.

Hutcheon, Linda (1985) A Theory of Parody. NewYork and London, Methuen:

Kamler, Barbara (1999) 'This lovely doll who's come to school: moming talk as gendered language practice' in Barbara Kamler (ed) Constructing Gender and Difference. New Jersey, Hampton Press, pp.191-213.

Kemp, Gene (1977) The Turbulent Term of Tyke Tiler. London, Faber and Faber.

Kipling, Rudyard (1987) [1899] Stalky and Co. Harmondsworth, Puffin.

Mackey, Margaret (1990) 'Metafiction for beginners: Allan Ahlberg's Ten in a Bed', Children's Literature in Education 21, 3 , 179-87.

McCallum, Robyn 1996 'Metafictions and experimental work' in Peter Hunt (ed) International Companion Encyclopedia of Children's Literature. New York and London, Routledge, pp.397-409.

McNaughton, Colin (1994) Captain Abdul's Pirate School. London, Walker Books.

Mark, Jan (1976) Thunder and Lightnings. Harmondsworth, Kestrel.

Moss, Geoff (1992) 'Metafiction, illustration and the poetics of children's literature', in Peter Hunt (ed) Literature for Children: Contemporary Criticism. London, Routledge, pp.44-66.

Partington, Gary (1998) 'From play school to peer groups: socialisation and socialising 
agencies' in Jennifer Allen (ed) Sociology of Education: Possibilities and Practices,

Katoomba, Social Science Press, pp.101-19.

Ray, Sheila (1996) 'School stories' in Peter Hunt (ed) International Companion Encyclopedia of Children's Literature. New York and London, Routledge, pp.348-59.

Rimmon-Kenan, Shlomith (1996) A Glance Beyond Doubt. Columbus, Ohio State University Press.

Stephens, John (1992) Language and Ideology in Children's Fiction. London and New York, Longman.

Watson, Ken (1987) 'The rise, fall and remarkable revival of the school story', in Maurice Saxby and Gordon Winch (eds) Give Them Wings: The Experience of Children's Literature. South Melboume, Macmillan, pp.196-208.

Wilson Keenan, Jo-Anne, Solsken, Judith and Willett , Jerri (1999) ' "Only boys can jump high": reconstructing gender relations in a first/second grade classroom' in Barbara Kamler (ed) Constructing Gender and Difference. New Jersey, Hampton Press, pp.33-70.

\section{ACKNOWLEDGEMENTS}

Thank you to John Stephens and to Bev Pennell for their helpful suggestions and comments.

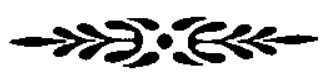

\section{BIOGRAPHICAL NOTE}

Cheryl McMillan is a Ph.D student at Macquarie University, where she is researching postmodernist forms in children's fiction. Her recent work on uses of parody and the carnivalesque has contributed to this article. Cheryl also teaches senior school English and at present privately tutors HSC students.

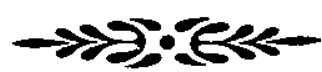

